(c) American Dairy Science Association, 2007.

\title{
Fertility of Lactating Dairy Cows Administered Recombinant Bovine Somatotropin During Heat Stress
}

\author{
F. D. Jousan, L. A. de Castro e Paula, J. Block, and P. J. Hansen ${ }^{1}$ \\ Department of Animal Sciences, University of Florida, Gainesville 32611-0910
}

\section{ABSTRACT}

Administration of recombinant bovine somatotropin (bST) to lactating dairy cows during heat stress increases milk yield, but it also can increase body temperature and may therefore compromise fertility. However, it is possible that bST treatment could increase fertility during heat stress because it has been reported to increase fertility in lactating cows. In addition, bST increases secretion of insulin-like growth factor-I (IGFI) that promotes embryo survival. The purpose of this study was to determine effects of bST on reproductive function in lactating dairy cows during heat stress. The experiment was conducted in southern Georgia from July to November 2005 using lactating Holstein cows ( $\mathrm{n}=276$ for reproductive traits). For first service timed artificial insemination (TAI), cows were presynchronized with 2 injections of $\mathrm{PGF}_{2 \alpha}$ given $14 \mathrm{~d}$ apart followed by a modified Ovsynch protocol ( $\mathrm{GnRH}$ and insemination at $72 \mathrm{~h}$ following $\mathrm{PGF}_{2 \alpha}$ ). Pregnancy was diagnosed by using ultrasonography on $\mathrm{d} 29$ and reconfirmed by palpation between d 45 and 80 post-TAI. Nonpregnant cows were resynchronized with the modified Ovsynch protocol and received a second TAI. Treatment with bST started 1 wk before the start of Ovsynch and continued at 2 -wk intervals. Blood samples were collected from a subset of cows to determine IGF-I profiles immediately before the first bST injection, $1 \mathrm{wk}$ later, and at d 35 of bST treatment. Rectal temperatures were assessed on d 29 of bST treatment. Pregnancy rates (d 45 to 80 post-TAI) did not differ between bST and control cows for first- (16.7 vs. $15.2 \%)$ or secondservice TAI ( 14.8 vs. $17.2 \%$ ). Plasma concentrations of IGF-I and milk yield were greater for bST-treated cows following the initiation of bST treatment and bST increased rectal and vaginal temperatures. Body condition score was less for bST-treated cows. In conclusion, treatment with bST during heat stress increased IGFI concentrations, milk yield over time, and rectal and vaginal temperatures without affecting first- or second-

Received June 21, 2006.

Accepted August 25, 2006.

${ }^{1}$ Corresponding author: hansen@animal.ufl.edu service pregnancy rates. Thus, at least under certain housing conditions, bST can be used to improve milk yield during heat stress without compromising fertility. Key words: dairy cow, bovine somatotropin, fertility, heat stress

\section{INTRODUCTION}

Treatment of lactating cows exposed to heat stress with bST can increase milk yield (West et al., 1990b; Elvinger et al., 1992). One consequence of bST treatment during heat stress is an increase in body temperature (Elvinger et al., 1992; Cole and Hansen, 1993) and some of this increase in body temperature may be independent of a lactational effect (Elvinger et al., 1992; Cole and Hansen, 1993). Given the fact that elevated body temperature compromises fertility in lactating cows (e.g., a $0.5^{\circ} \mathrm{C}$ increase in uterine temperature on the day of insemination resulted in a $12.8 \%$ decrease in fertility; Gwazdauskas et al., 1973), it is possible that bST treatment during heat stress could compromise fertility. However, fertility-promoting effects of bST may overcome adverse effects of increased hyperthermia on fertility. Indeed, treatment of dairy cows with bST increased fertility (Moreira et al., 2000b, 2001; Santos et al., 2004).

Treatment with bST also may increase cellular resistance to elevated temperature, either directly or indirectly. Lymphocytes harvested from heifers treated with bST were more resistant to heat shock in vitro compared with lymphocytes from nontreated heifers (Elvinger et al., 1991). Insulin-like growth factor-I, whose secretion is induced by bST (Bilby et al., 1999), reduced the effects of heat shock on development and apoptosis in preimplantation bovine embryos (Jousan and Hansen, 2004, 2006).

Given the fertility promoting and thermoprotective actions of bST, the hypothesis of this study was that administration of bST to lactating Holstein cows during summer would increase pregnancy rates compared with lactating nontreated Holstein cows.

\section{MATERIALS AND METHODS}

\section{Animals, Housing, and Feeding}

The experiment was conducted from July 4 to November 7, 2005, at a commercial dairy near Quitman, GA 
$\left(30^{\circ} 47^{\prime} 5^{\prime \prime} \mathrm{N}, 83^{\circ} 33^{\prime} 39^{\prime \prime} \mathrm{W}\right)$ utilizing 285 lactating Holstein cows (94 were primiparous and 191 were multiparous). The University of Florida Institutional Animal Care and Use Committee approved the experimental protocol. During the study period, cows were housed in a free-stall barn equipped with fans and a sprinkler system. Hourly dry-bulb temperature and relative humidity measurements were recorded at a height of $3 \mathrm{~m}$ inside the free-stall barn from July 18 to November 7, 2005, using a data logger (HOBO Pro RH/Temp Data Logger, Onset Computer Co., Bourne, MA); results are depicted in Figure 1.

All cows were fed as a group twice daily. The diet was a TMR containing corn silage and ryegrass silage as the main ingredients and with $0.80 \mathrm{Mcal}$ of $\mathrm{NE}_{\mathrm{L}} / \mathrm{kg}$ and $17.18 \% \mathrm{CP}$ on a DM basis. Cows were milked thrice daily $(0000,0800$, and $1600 \mathrm{~h})$ and milk yields were recorded for individual cows once monthly during the official Georgia DHIA test.

\section{Experimental Design}

A diagram of the experimental protocol is displayed in Figure 2. For first-service timed AI (TAI), estrous cycles in cows at an average of $44 \mathrm{~d}$ postpartum (range 41 to $47 \mathrm{~d}$ ) were presynchronized with 2 injections of $25 \mathrm{mg}$ of $\mathrm{PGF}_{2 \alpha}$, i.m. $14 \mathrm{~d}$ apart, followed $14 \mathrm{~d}$ later by the initiation of a modified Ovsynch protocol $(100 \mu \mathrm{g}$ of $\mathrm{GnRH}$, i.m. followed $7 \mathrm{~d}$ later with $25 \mathrm{mg}$ of $\mathrm{PGF}_{2 \alpha}$, i.m., and a second injection of GnRH (100 $\mu \mathrm{g})$ given 72 $\mathrm{h}$ following $\mathrm{PGF}_{2 \alpha}$ coincident with TAI; Portaluppi and Stevenson, 2005). All cows received an additional 100$\mu \mathrm{g}$ injection of GnRH, i.m., 1 wk before pregnancy diagnosis was conducted by using ultrasonography on d 29 post-TAI. Estrous cycles in cows diagnosed nonpregnant were resynchronized with the continuation of the modified Ovsynch protocol and received TAI. Pregnancy for first and second service was confirmed by palpation per rectum between d 45 and 80 post-TAI.

Cows were enrolled in the experiment each week (during an 8-wk period) and were assigned randomly to receive bST or serve as controls within each week block. Overall, an equal number of primiparous cows were assigned per treatment $(n=47)$, whereas 103 and 88 multiparous cows were assigned to bST treatment and control, respectively. Treatment with bST (500 mg, s.c.; Posilac, Monsanto Co., St. Louis, MO) was initiated $1 \mathrm{wk}$ before the start of the modified Ovsynch protocol and continued at 2 -wk intervals throughout the experiment. Treatment was administered initially in the depression on the right side of the tail head with subsequent injections being alternated between the cow's left and right side tail head depression. Control cows received no injection.
Body condition score using a scale of 1 to 5 in 0.25 increments (Edmonson et al., 1989) was recorded for bST-treated and control cows at each bST treatment. Each week, a subset of 3 cows per treatment was fitted with a temperature data logger (HOBO Water Temp Pro v1, Onset Computer Co.) attached to a blank control internal drug release (CIDR) insert (Pfizer Animal Health, New York, NY) that was inserted into the vagina. The data logger recorded vaginal temperature at 15 -min intervals beginning at $1200 \mathrm{~h}$ on $\mathrm{d} 11$ post-TAI for 1 wk starting at d 28 of bST treatment. A new subset of cows was enrolled each week so that vaginal temperatures were recorded from $21 \mathrm{bST}$ and 20 control cows in total. In addition, rectal temperatures were taken between 1600 and $2000 \mathrm{~h}$ on d 11 post-TAI (d 29 of bST treatment) for all cows, using a digital thermometer (M525/550 Hi-Performance Digital Thermometer; GLA Agricultural Products, San Luis Obispo, CA). Rectal temperatures were recorded following the milking that occurred at $1600 \mathrm{~h}$, when the cows had been washed in preparation for milking and kept under fans while in the milking parlor.

\section{Blood Sample Collection and IGF-I Immunoradiometric Assay}

Blood samples were collected from a subset of cows $(\mathrm{n}=27)$ to determine IGF-I concentrations immediately before the first bST injection, 1 wk later, and at d 35 of bST treatment. Blood samples were collected by coccygeal venipuncture into evacuated heparinized $10-\mathrm{mL}$ tubes (Becton Dickinson, Franklin Lakes, NJ). Following collection, blood samples were placed in an ice chest until further processing at the laboratory (within approximately 4 to $6 \mathrm{~h}$ ). Blood samples were centrifuged at $2,000 \times \mathrm{g}$ for $20 \mathrm{~min}$ at $4^{\circ} \mathrm{C}$. Plasma was separated and stored at $-20^{\circ} \mathrm{C}$ until assayed for IGF-I concentration, which was determined using the ACTIVE NonExtraction IGF-I IRMA kit (DSL-2800; Diagnostic Systems Laboratories, Inc., Webster, TX) according to the manufacturer's protocol. The assay had a sensitivity of $2.06 \mathrm{ng} / \mathrm{mL}$ ( 2 standard deviations below the $0 \mathrm{ng} / \mathrm{mL}$ IGF-I standard) as determined by the manufacturer. The assay was validated for parallelism by using different dilutions of a plasma sample. All samples were assayed at the same time and the intraassay coefficient of variation was $7 \%$.

\section{Statistical Analysis}

Nine cows were excluded from the statistical analysis (3 control cows, $2.2 \%$; and 6 bST cows, $4.0 \%$ ) because they were removed from the herd before pregnancy diagnosis at $d 29$ post-TAI, thereby leaving 276 total cows [n $=132$ control cows (46 first-lactation cows and 86 


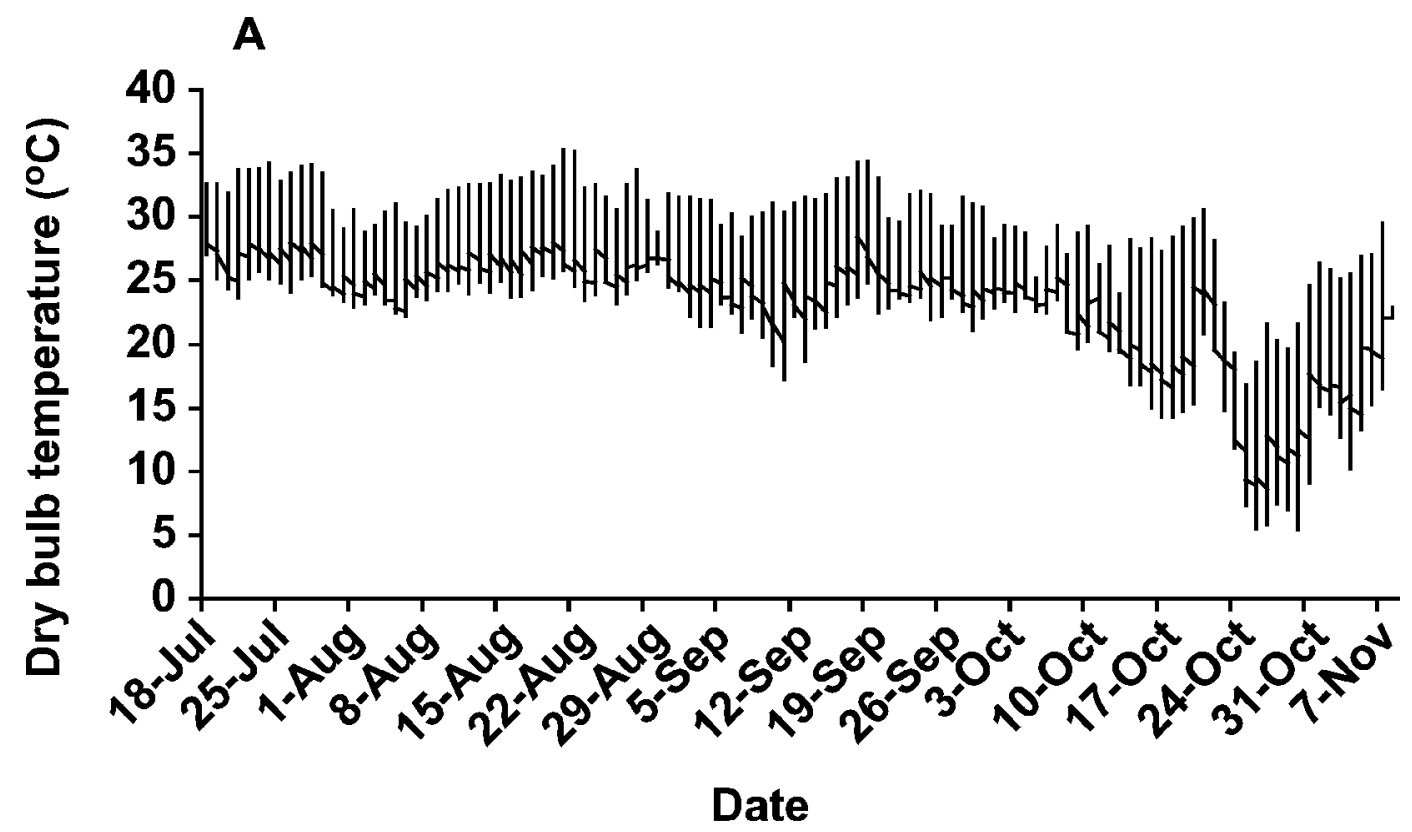

B

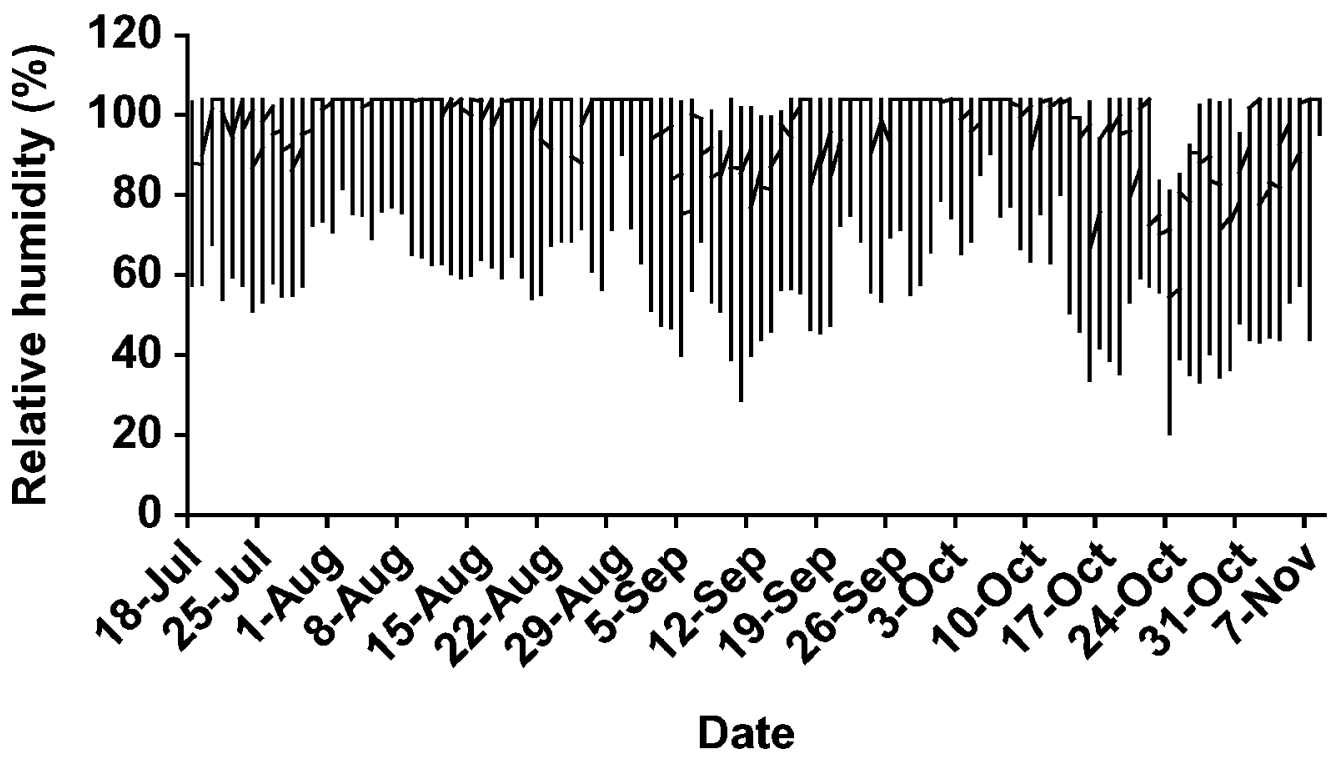

Figure 1. Daily dry bulb temperature (A) and relative humidity (B) at the experimental site from July 18 to November 7, 2005. Data, which were recorded in the free-stall barn at a height of $3 \mathrm{~m}$, represent hourly averages of measurements collected every 15 min.

cows in their second or greater lactation) and $\mathrm{n}=144$ bST cows (44 first-lactation cows and 100 cows in their second or greater lactation)] for analysis of pregnancy rate.

Statistical analysis was performed to determine the effects of bST and other dependent variables. Days in milk class (DIMC) divided cows based on DIM: $<63 \mathrm{~d}$ or $\geq 63 \mathrm{~d}$ at the start of bST treatment. Milk yield class (MYC) categorized cows based on milk yield at the monthly DHIA test date immediately before the start of
bST treatment. Classes, which were based on quartiles derived from the Univariate procedure of SAS (SAS Inst., Inc., Cary, NC), were $<31.7 \mathrm{~kg} / \mathrm{d}, 31.7$ to $<39.1$ $\mathrm{kg} / \mathrm{d}, 39.1$ to $<45.9 \mathrm{~kg} / \mathrm{d}$, or $\geq 45.9 \mathrm{~kg} / \mathrm{d}$. Finally, cows were categorized according to BCS class (BCSC) into classes of $\mathrm{BCS}<2.5$, equal to 2.5 , or $>2.5$ at the start of bST treatment. All cows were separated based on parity into first-lactation cows and cows with $\geq 2$ lactations.

First- and second-service TAI pregnancy rates and pregnancy loss were analyzed with the LOGISTIC pro- 

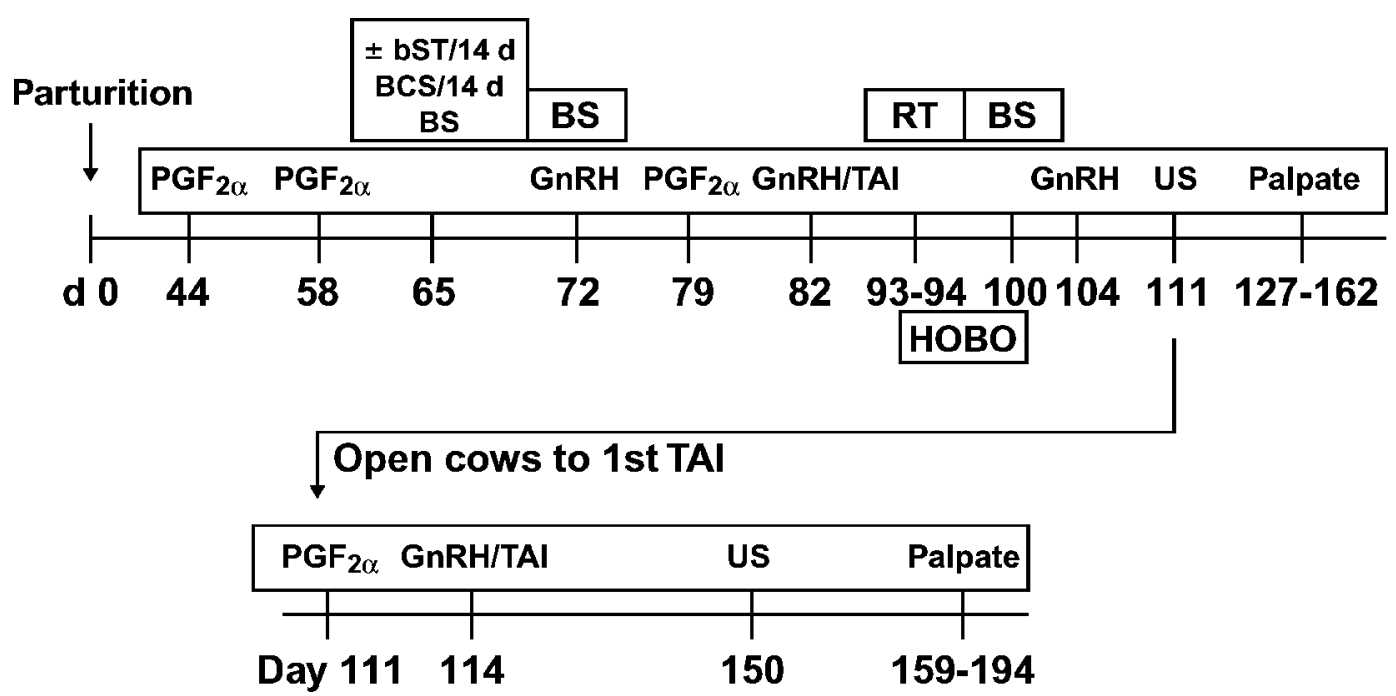

Figure 2. Schematic diagram illustrating the time course of the experiment. $\mathrm{BS}=$ blood sample; $\mathrm{TAI}=$ timed $\mathrm{AI} ; \mathrm{RT}=$ rectal temperature; $\mathrm{HOBO}=\mathrm{HOBO}$ device for measuring vaginal temperature; US = ultrasound.

cedure of SAS using a backward stepwise logistic model. Variables were continuously removed from the model by the Wald statistic criterion if the significance was $>0.20$. The mathematical model for analysis of firstand second-service TAI pregnancy rates and pregnancy loss included the effects of bST, sire, technician, week of insemination, parity, MYC, DIMC, BCSC, and bST $\times$ parity, $\mathrm{bST} \times \mathrm{MYC}, \mathrm{bST} \times \mathrm{DIMC}$, and $\mathrm{bST} \times \mathrm{BCSC}$. No significant interactions were found, however, and the final model included only main effects. Adjusted odds ratio (AOR) estimates and the 95\% Wald confidence intervals $(\mathbf{C I})$ from logistic regression were obtained for each variable that remained in the final statistical model following the backward elimination. The Wald $\chi^{2}$ statistic was used to determine the probability value for each main effect that remained in the reduced model (significance was considered as $P<0.05$ ). In addition, differences between levels of variables having more than 1 degree of freedom were determined using the GENMOD procedure of SAS.

Treatment effects on concentration of IGF-I, milk yield, BCS, rectal temperature, and vaginal temperature were analyzed using least squares ANOVA with the GLM procedure of SAS. Tests of significance were made using the appropriate error terms based on calculation of expected means squares. Cow was a random effect and other main effects were considered fixed.

Because only a subset of cows was bled to determine the concentration of plasma IGF-I, the model included main effects of bST, time, cow nested within bST and the interaction of bST $\times$ time.

Initial analysis of milk yield used data for the 3 monthly test dates before the start of bST treatment and the 4 monthly test dates following the start of bST treatment. The model included main effects of bST, parity, time, BCSC, and cow (nested within bST, parity, and BCSC) and interactions between main effects. Other analyses were performed using datasets consisting of each test date separately for the 4 monthly test dates following the start of bST treatment. In this case, DIM and milk yield at the test date immediately before the start of bST treatment were used as covariates. The model also included effects of bST, parity, BCSC, bST $\times$ parity, and bST $\times$ BCSC.

Body condition score was analyzed by ANOVA using the main effects of bST, parity, time, cow nested within bST and parity, and interactions between main effects. Change in BCS from the start of bST treatment until the end of the experiment was calculated as the final BCS at wk 12 minus the initial BCS at wk 0. This variable was analyzed using least squares ANOVA to determine the effects of bST, parity, and bST $\times$ parity. In addition, BCS at each measurement date were further analyzed using the CATMOD procedure of SAS with the main effect of bST treatment.

Rectal temperature data were analyzed using the main effects of bST, parity, MYC, and BCSC, and interactions between main effects. Because only a subset of cows was fitted vaginally with a HOBO digital temperature recorder, the statistical model to determine effects on vaginal temperature included effects of bST, cow nested within bST, time and the interaction of bST $\times$ time. Unless otherwise mentioned, all values reported for IGF-I concentration, milk yield, BCS, rectal temperature, and vaginal temperature are least squares means \pm SEM. 


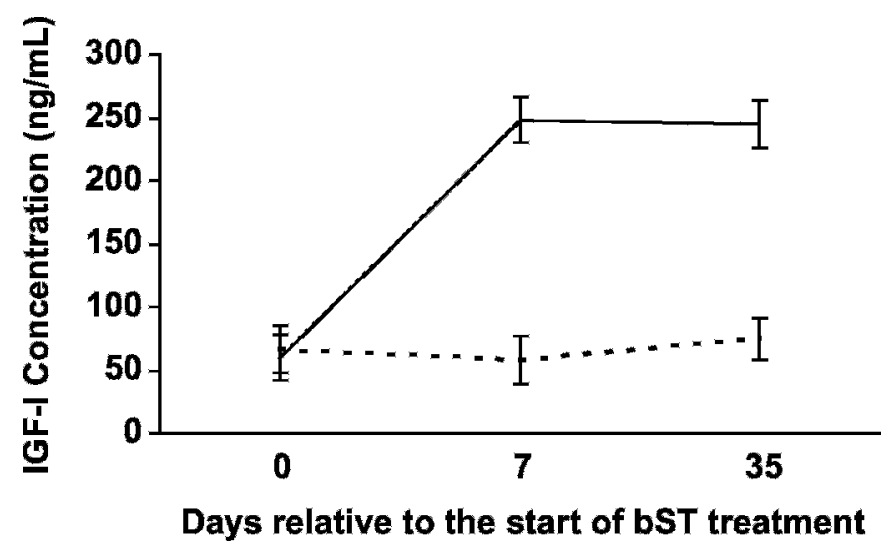

Figure 3. Plasma IGF-I response to bST. Depicted are the concentrations of plasma IGF-I for bST (solid line) and control cows (dashed line) at d 0 (initiation of bST treatment), 7 , and 35 relative to the start of bST treatment. Data represent least squares means \pm SEM. Cows treated with bST had increased (bST $\times$ time, $P<0.001$ ) concentrations of plasma IGF-I at $d 7$ and 35 as compared with control cows.

\section{RESULTS}

Plasma IGF-I concentrations were similar for bST and control cows before the start of bST treatment (Figure 3). Concentrations remained constant thereafter for control cows, but increased (bST $\times$ time: $P<0.001$ ) approximately 4 -fold at $\mathrm{d} 7$ and 35 after treatment in the bST-treated group.

Milk yields were similar between bST and control cows before the start of bST treatment, but bST cows had greater $(\mathrm{bST} \times$ time; $P<0.05)$ milk yields than control cows after the initiation of bST treatment (Figure $4 \mathrm{~A}$ ). Increase in milk yield at each test date due to bST ranged from 8 to $12 \%$ and from 2.4 to $3.7 \mathrm{~kg} / \mathrm{d}$. Cows in their second or greater lactation had a greater $(P<0.001)$ milk yield $(37.2 \pm 0.6 \mathrm{~kg})$ than lactating heifers in their first lactation $(28.5 \pm 0.9 \mathrm{~kg})$, but there was no interaction between bST $\times$ parity. A separate analysis of milk yield following the start of bST treatment was conducted in which DIM and milk yield at the test date immediately before the start of bST treatment were covariates. Cows treated with bST had greater $(P$ $<0.001$ ) milk yield when compared with control cows at each of the monthly test dates following the start of bST (Figure 4B).

Rectal temperature on d 29 of bST treatment was greater $(P<0.05)$ for bST cows compared with control cows (Figure 5A). In addition, vaginal temperature recorded every 15 min from d 28 to 35 of bST treatment was greater $(P<0.05)$ for bST cows compared with control cows (Figure 5B). The time of day $\times$ bST treatment interaction was not significant.

Body condition score was affected $(P<0.05)$ by an interaction of bST $\times$ time (Figure $6 \mathrm{~A}$ ). Before initiation of bST treatment, BCS were similar for control and bST cows and increased over time. Following initiation of bST, BCS declined in both groups of cows and the loss in BCS was more pronounced for bST cows. There was also an effect $(P<0.05)$ of bST treatment on the net change in BCS from the initial to final BCS measurement $(+0.05$ and +0.14 for bST-treated and control cows, respectively, SEM = 0.03). As an additional test of effects of bST on BCS, data at each measurement were analyzed separately by CATMOD analysis to determine whether bST affected the distribution of BCS. A representative example of the effects of bST on distribution of BCS is shown for wk 10 after bST (Figure 6B). Treatment with bST affected distribution of BCS at wk 8 ( $P$ $<0.001), 10(P<0.001)$, and $12(P<0.05)$ after bST.

Pregnancy rates following the first- and second-service TAI for bST and control cows are depicted in Figure 7. For first-service TAI (Figure 7A), there was no significant difference in pregnancy rate on d 29 post-TAI between bST-treated $(18.8 \% ; 27$ cows pregnant/144 cows total) vs. control cows (17.4\%; 23/132). Similarly, pregnancy rate based on palpation at $\mathrm{d} 45$ to 80 postTAI was not different between bST-treated cows (16.7\%; 24/144) and control cows (15.2\%; 20/132). In addition, there was no effect of bST on pregnancy loss between the 2 diagnoses of pregnancy [11.1\% (3/27) for bST vs. $13.0 \%$ (3/23) for control]. For the second-service TAI (Figure 7B), no pregnancy loss was detected between the 2 pregnancy diagnoses. Thus, pregnancy rates were the same at both times and were $14.8 \%$ (9/ 61) for bST cows and 17.2\% (11/64) for control cows. The effect of bST was not significant.

The BCSC influenced $(P<0.05)$ first-service pregnancy rate based on palpation. Those cows categorized as having a BCS $<2.5,2.5$, or $>2.5$ had a first-service pregnancy rate of $9.6 \%$ (5/52), $12.8 \%$ (18/141), and $25.3 \%$ (21/83), respectively. The AOR for first-service pregnancy rate for cows categorized with a BCS $>2.5$ compared with cows with a BCS $<2.5$ was $3.37(95 \%$ Wald CI: $1.18,9.66 ; P<0.05$ ), whereas the AOR for first-service pregnancy rate for cows categorized with a BCS $>2.5$ compared with cows with a BCS of 2.5 was 2.21 (95\% Wald CI: $1.09,4.47 ; P<0.05$ ). For the secondservice TAI, there was no effect of BCSC on pregnancy rate at d 45 to 80 post-TAI [pregnancy rates were $15.2 \%$ (5/33), $16.7 \%$ (11/66), and $15.4 \%$ (4/26) for cows with a $\mathrm{BCS}<2.5,2.5$, or $>2.5$, respectively].

\section{DISCUSSION}

Results from the present study indicate that bST can be administered to lactating Holstein cows during summer heat stress to increase milk yield without compro- 

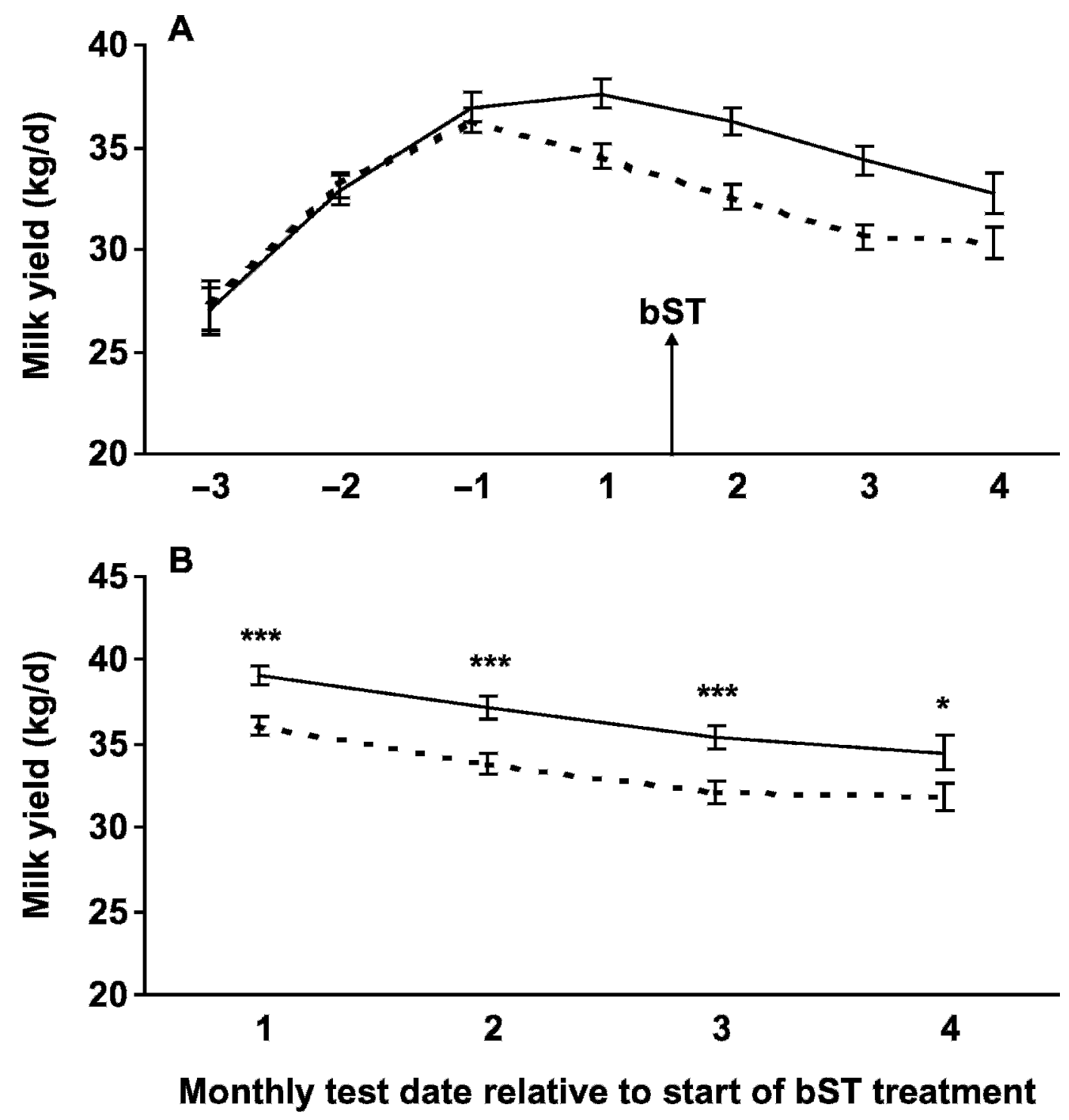

Figure 4. Milk yield responses to bST. Panel A depicts milk yield collected at each monthly Georgia DHIA test date for bST (solid line) and control cows (dashed line) throughout the experiment. Panel B represents milk yield responses for bST (solid line) and control cows (dashed line) after the start of bST treatment after adjustment with DIM and milk yield at the test date immediately before the start of bST treatment as covariates. Data represent least squares means \pm SEM. In Panel A, milk yield was affected by bST $\times$ time $(P<0.01)$. For panel $\mathrm{B}$, asterisks $(* P<0.05$; $* * * P<0.001)$ represent differences between bST and control cows.

mising first- or second-service TAI pregnancy rates. Thus, despite the increased response expressed as increased milk yield and body temperature and reduced BCS, cows treated with bST remained as fertile as control cows. Pregnancy rates achieved by TAI were similar to what has been reported for other lactating cows exposed to heat stress (Aréchiga et al., 1998; Franco et al., 2006). That bST did not reduce pregnancy rates despite increasing body temperature may be the result of the fertility-promoting effects of this hormone (Moreira et al., 2000b, 2001; Santos et al., 2004) and the actions of bST and IGF-I to increase cellular resistance to elevated temperature (Elvinger et al., 1991; Jousan and Hansen, 2004, 2006).

As reported previously (Bilby et al., 1999), bST caused a large increase in plasma IGF-I concentrations, indicating that heat stress does not block the IGF-I response to bST. The increase in milk yield in response to 500 mg of bST administered every other week, whether expressed on an absolute basis (2.4 to $3.7 \mathrm{~kg} / \mathrm{d}$ ) or a percentage basis ( 8 to 12\%), was similar to what has been observed for nonheat-stressed cows (Bauman et al., 1999; Santos et al., 2004; VanBaale et al., 2005). Indeed, several studies have shown that bST increases milk 

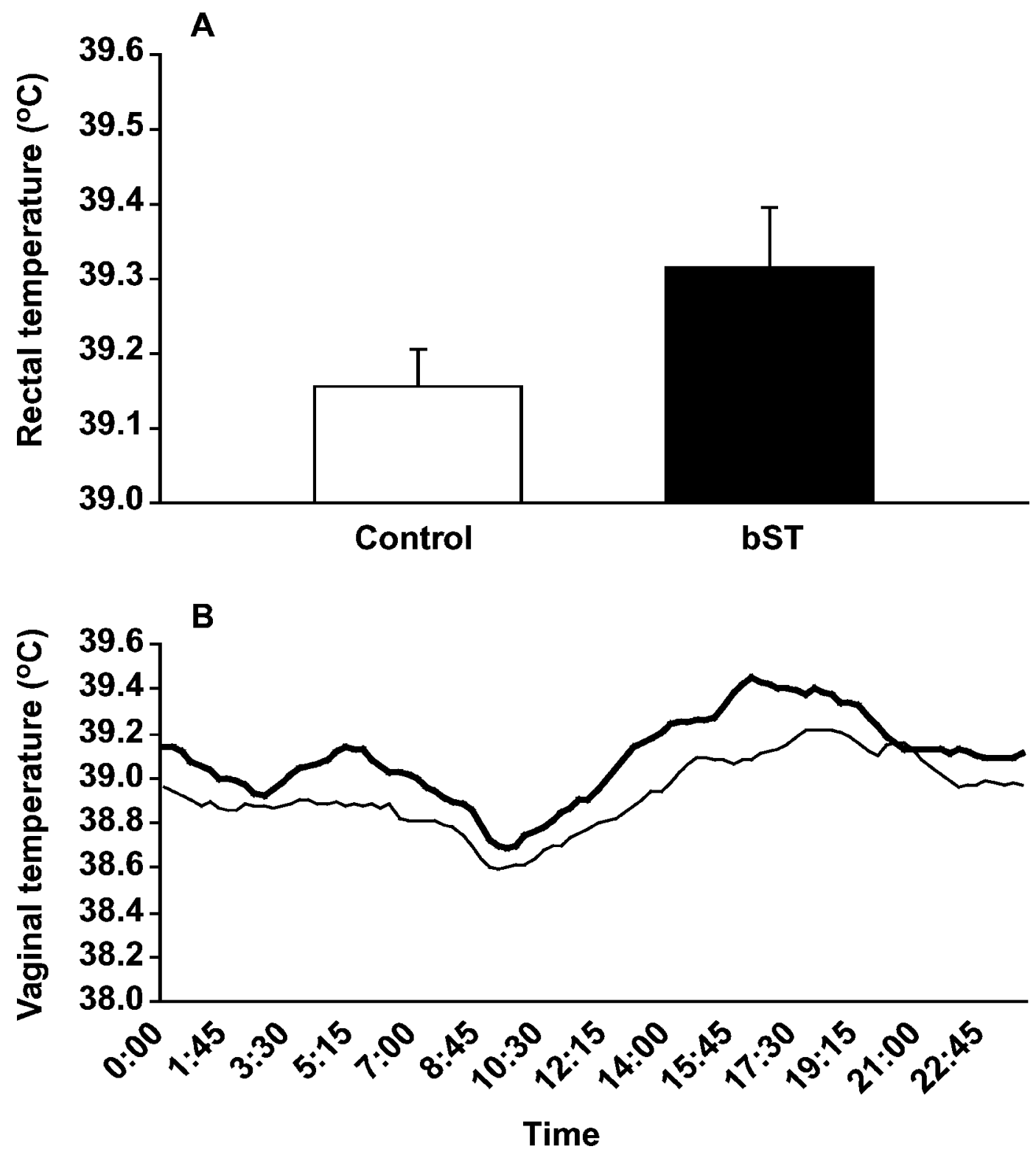

Figure 5. Rectal and vaginal temperatures as affected by bST. Panel A represents the rectal temperature for bST (filled bar) and control cows (open bar) measured between 1600 and $2000 \mathrm{~h}$ on d 29 of bST treatment. Panel B depicts the vaginal temperature for bST (thick solid line) and control cows (thin line) recorded every 15 min between d 28 and 35 of bST treatment. Data in both panels represent least-squares means \pm SEM. Treatment of cows with bST increased $(P<0.05)$ rectal (panel A) and vaginal temperature (panel B) compared with control cows. No time $\times$ bST treatment interaction was detected for vaginal temperature.

yield of cows under conditions of heat stress here and in other studies (West et al., 1990b; Elvinger et al., 1992).

Cows treated with bST experienced greater body temperatures than control cows (West et al., 1990b; Elvinger et al., 1992; Cole and Hansen, 1993). Vaginal temperatures indicated that this difference persisted throughout the day and that bST-treated cows were hyperthermic nearly continuously. The increase in body temperature caused by bST could be because of the increase in milk yield caused by bST treatment. There is the possibility for effects of bST independent of lactation. Elvinger et al. (1992) found that treatment of cows in Florida with bST during summer increased rectal temperature even though there were little absolute differences in milk yield between bST and control cows. In addition, bST increased body temperature and rate of open-mouthed panting for nonlactating cows exposed to heat stress (Cole and Hansen, 1993).

Effects of bST on body temperature could be expected to decrease fertility because fertility declines as body 

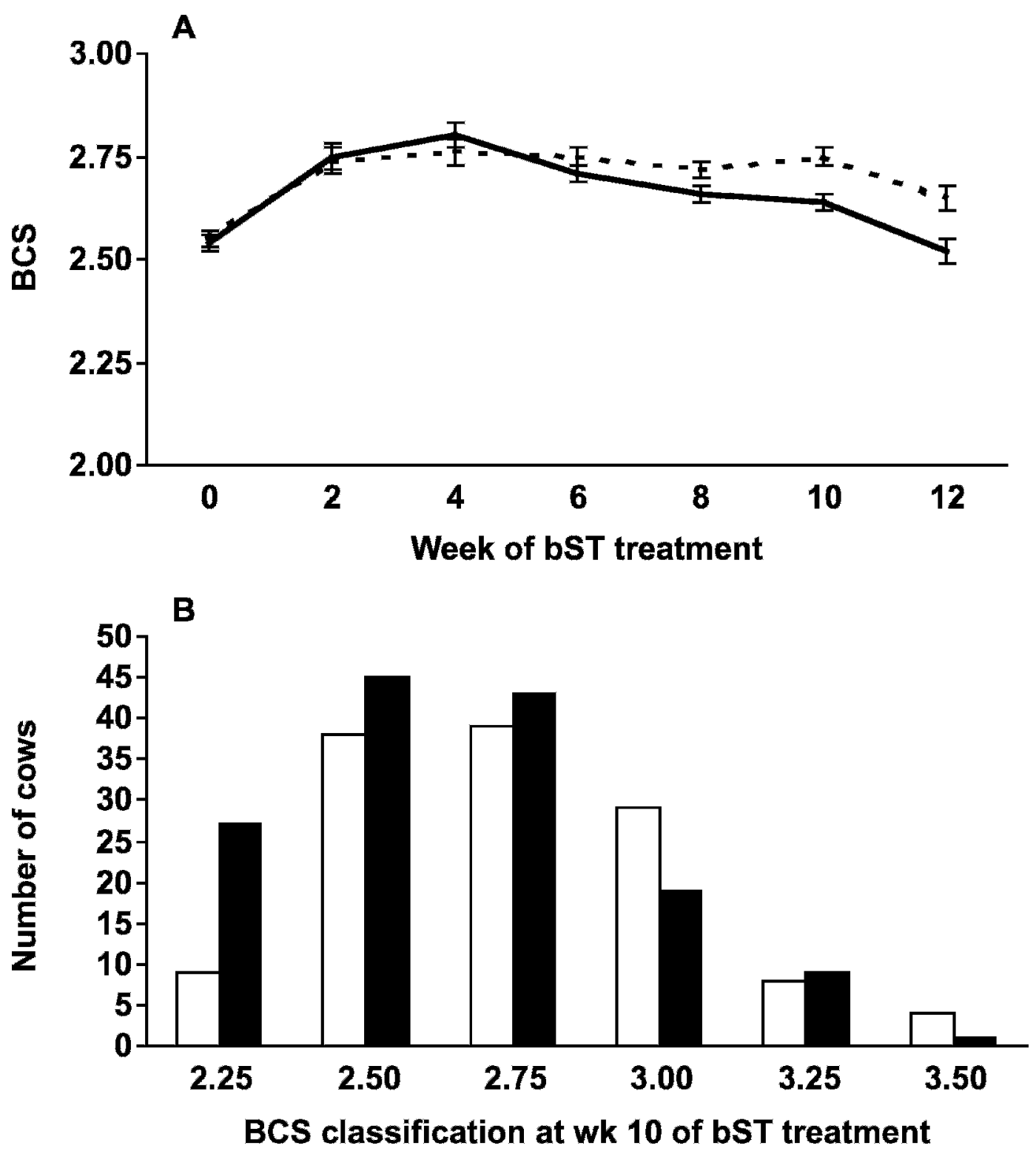

Figure 6. Effect of bST on BCS. Panel A depicts BCS for bST (solid line) and control cows (dashed line) throughout the experiment. Data represent least squares means \pm SEM. In panel A, bST-treated cows lost more $(P<0.05)$ body condition over time as compared with the control cows. Panel B represents the distribution of BCS at wk 10 after initiation of bST for bST-treated (black bar) and control cows (white bar). Treatment with bST affected $(P<0.001)$ distribution of BCS.

temperature rises (Vasconcelos et al., 2006). That such a negative effect of bST on fertility was not seen implies that other effects of bST compensated for the increased body temperature. One possibility is that bST or IGFI increases resistance of embryos to elevated temperature. Lymphocytes from bST-treated heifers were more resistant to the effects of heat shock in culture than lymphocytes from control heifers (Elvinger et al., 1991). Also, IGF-I can protect embryos from effects of heat shock on development and apoptosis (Jousan and Hansen, 2004, 2006). Bovine somatotropin also can have fertility-enhancing effects in lactating cows not subjected to heat stress (Moreira et al., 2000b, 2001; Santos et al., 2004). The mechanisms responsible for this effect of bST are not clear but could involve increased weight of the corpus luteum (Lucy et al., 1995), increased number of follicles 10 to $15 \mathrm{~mm}$ in diameter (Lucy et al., 1995), increased fertilization rates (Moreira et al., 2002a), IGF-I-mediated changes in rate of early embryonic development (Moreira et al., 2002b; Block et al., 2003), and embryonic apoptosis (Jousan and Hansen, 2004, 2006), modulation of $\mathrm{PGF}_{2 \alpha}$ synthesis (Badinga 

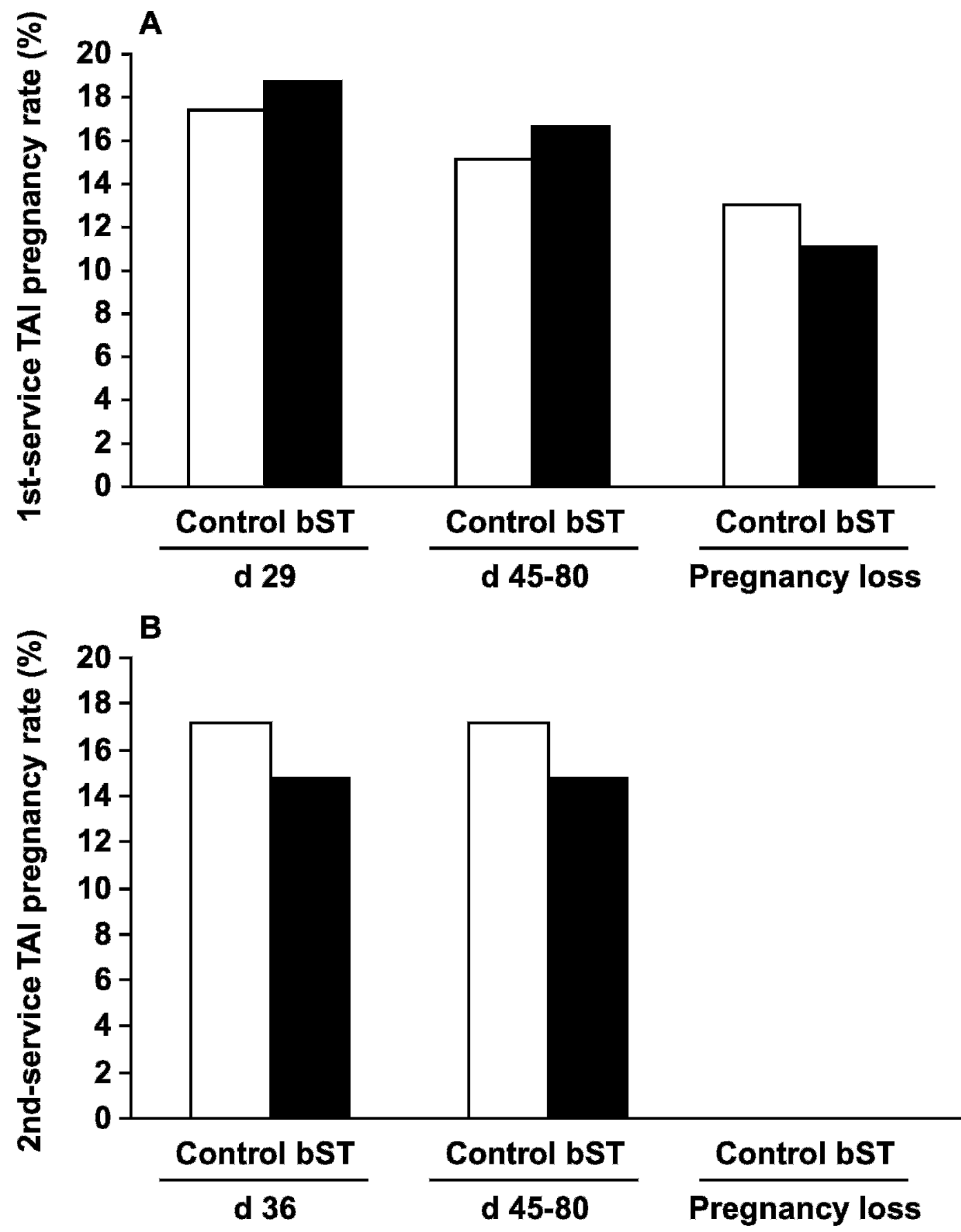

Figure 7. Pregnancy rates and losses for control and bST cows following first- and second-service timed AI (TAI). Panel A represents the first-service TAI pregnancy rates for bST (black bar) and control cows (white bar) at d 29 post-TAI as determined by ultrasonography, pregnancy rate at d 45 to 80 post-TAI as determined by rectal palpation, and the percentage of pregnancies lost between d 29 and the second pregnancy diagnosis. Panel B represents the second-service TAI pregnancy rates for bST (black bar) and control cows (white bar) at d 36 post-TAI as determined by ultrasonography, pregnancy rate at d 45 to 80 post-TAI as determined by rectal palpation, and the percentage of pregnancies lost between $\mathrm{d} 36$ and the second pregnancy diagnosis. Note that no pregnancies were lost.

et al., 2002), and effects on the oviduct and uterus (Pershing et al., 2002).

In the current study, cows classified as having a BCS of $<2.5$ or equal to 2.5 had a reduced first-service TAI pregnancy rate (d 45 to 80 post-TAI) compared with cows with a BCS of $>2.5(9.6,12.8$, and $25.3 \%$ firstservice TAI pregnancy rate for cows classified as having a $\mathrm{BCS}$ of $<2.5$, equal to 2.5 , and $>2.5$, respectively). 
Reduced fertility associated with low BCS has been reported previously (Moreira et al., 2000a; Buckley et al., 2003). Some of the reduced pregnancy rate in cows having poor BCS is likely to have been caused by failure of cows to resume ovarian cyclicity at first service (Shrestha et al., 2005). The fact that BCS did not affect second-service TAI pregnancy rate could indicate that the major effect of BCS is on resumption of cyclicity, assuming most cows had resumed estrous cycles by second insemination.

In the current study, bST reduced BCS, but the magnitude of the effect was probably too small to compromise reproductive function. Reduction in BCS caused by bST was likely caused by mobilization of NEFA from adipose tissue (Tarazón-Herrera et al., 1999). Other studies have found that cows administered bST lost BW and body condition (West et al., 1990a,b), although Johnson et al. (1991) reported no change in BW in bSTtreated cows.

In conclusion, this study demonstrated that treatment of lactating Holstein cows with bST during heat stress increased concentrations of IGF-I and milk yield. In addition, bST-treated cows had increased rectal and vaginal temperatures and lost slightly more body condition over time than control cows. Despite these changes, first- and second-service TAI pregnancy rates and pregnancy losses were not reduced, indicating that, at least under certain housing conditions, bST can be administered to lactating cows during heat stress without compromising fertility.

\section{ACKNOWLEDGMENTS}

The authors express their appreciation to A. M. Brad, B. Loureiro, M. B. Padua, K. Hendricks, P. Thompson, M. Franco, Calvin Moody, and the farm personnel at Brooksco Dairy (Quitman, GA) for assistance with the experiment. The authors also thank Monsanto Co. (St. Louis, MO) for donation of Posilac. The following competitive grants from the USDA Cooperative State Research, Education, and Extension Service supported some of the research: Grant No. 2004-34135-14715 from the Tropical Subtropical Agricultural Research Program and Grant No 2001-52101-11318 from the Initiative for Future Agricultural and Food Systems Program.

\section{REFERENCES}

Aréchiga, C. F., C. R. Staples, L. R. McDowell, and P. J. Hansen. 1998. Effects of timed insemination and supplemental beta-carotene on reproduction and milk yield of dairy cows under heat stress. J. Dairy Sci. 81:390-402.

Badinga, L., A. Guzeloglu, and W. W. Thatcher. 2002. Bovine somatotropin attenuates phorbol ester-induced prostaglandin $\mathrm{F}_{2 \alpha}$ production in bovine endometrial cells. J. Dairy Sci. 85:537-543.
Bauman, D. E., R. W. Everett, W. H. Weiland, and R. J. Collier. 1999. Production responses to bovine somatotropin in northeast dairy herds. J. Dairy Sci. 82:2564-2573.

Bilby, C. R., J. F. Bader, B. E. Salfen, R. S. Youngquist, C. N. Murphy, H. A. Garverick, B. A. Crooker, and M. C. Lucy. 1999. Plasma GH, IGF-I, and conception rate in cattle treated with low doses of recombinant bovine GH. Theriogenology 51:1285-1296.

Block, J., M. Drost, R. L. Monson, J. J. Rutledge, R. M. Rivera, F. F. Paula-Lopes, O. M. Ocon, C. E. Krininger, III, J. Liu, and P. J. Hansen. 2003. Use of insulin-like growth factor-I during embryo culture and treatment of recipients with gonadotropin-releasing hormone to increase pregnancy rates following the transfer of in vitro-produced embryos to heat-stressed, lactating cows. J. Anim. Sci. 81:1590-1602.

Buckley, F., K. O'Sullivan, J. F. Mee, R. D. Evans, and P. Dillon. 2003. Relationships among milk yield, body condition, cow weight, and reproduction in spring-calved Holstein-Friesians. J. Dairy Sci. 86:2308-2319.

Cole, J. A., and P. J. Hansen. 1993. Effect of administration of recombinant bovine somatotropin on the responses of lactating and nonlactating cows to heat stress. J. Am. Vet. Med. Assoc. 203:113-117.

Edmonson, A. J., I. J. Lean, L. D. Weaver, T. Farver, and G. Webster. 1989. A body condition scoring chart for Holstein dairy cows. J. Dairy Sci. 72:68-78.

Elvinger, F., P. J. Hansen, H. H. Head, and R. P. Natzke. 1991. Actions of bovine somatotropin on polymorphonuclear leukocytes and lymphocytes in cattle. J. Dairy Sci. 74:2145-2152.

Elvinger, F., R. P. Natzke, and P. J. Hansen. 1992. Interactions of heat stress and bovine somatotropin affecting physiology and immunology of lactating cows. J. Dairy Sci. 75:449-462.

Franco, M., P. M. Thompson, A. M. Brad, and P. J. Hansen. 2006. Effectiveness of administration of gonadotropin-releasing hormone at days 11, 14 or 15 after anticipated ovulation for increasing fertility of lactating dairy cows and non-lactating heifers. Theriogenology 66:945-954.

Gwazdauskas, F. C., W. W. Thatcher, and C. J. Wilcox. 1973. Physiological, environmental, and hormonal factors at insemination which may affect conception. J. Dairy Sci. 56:873-877.

Johnson, H. D., R. Li, W. Manalu, K. J. Spencer-Johnson, B. A. Becker, R. J. Collier, and C. A. Baile. 1991. Effects of somatotropin on milk yield and physiological responses during summer farm and hot laboratory conditions. J. Dairy Sci. 74:1250-1262.

Jousan, F. D., and P. J. Hansen. 2004. Insulin-like growth factor-I as a survival factor for the bovine preimplantation embryo exposed to heat shock. Biol. Reprod. 71:1665-1670.

Jousan, F. D., and P. J. Hansen. 2006. Insulin-like growth factor-I promotes resistance of bovine preimplantation embryos to heat shock through actions independent of its anti-apoptotic actions requiring PI3K signaling. Mol. Reprod. Dev. doi:10.1002/ $\operatorname{mrd} .20527$

Lucy, M. C., W. W. Thatcher, R. J. Collier, F. A. Simmen, Y. Ko, J. D. Savio, and L. Badinga. 1995. Effects of somatotropin on the conceptus, uterus, and ovary during maternal recognition of pregnancy in cattle. Domest. Anim. Endocrinol. 12:73-82.

Moreira, F., L. Badinga, C. Burnley, and W. W. Thatcher. 2002a. Bovine somatotropin increases embryonic development in superovulated cows and improves post-transfer pregnancy rates when given to lactating recipient cows. Theriogenology 57:1371-1387.

Moreira, F., C. Orlandi, C. A. Risco, R. Mattos, F. Lopes, and W. W. Thatcher. 2001. Effects of presynchronization and bovine somatotropin on pregnancy rates to a timed artificial insemination protocol in lactating dairy cows. J. Dairy Sci. 84:1646-1659.

Moreira, F., F. F. Paula-Lopes, P. J. Hansen, L. Badinga, and W. W. Thatcher. 2002b. Effects of growth hormone and insulin-like growth factor-I on development on in vitro derived bovine embryos. Theriogenology 57:895-907.

Moreira, F., C. A. Risco, M. F. A. Pires, J. D. Ambrose, M. Drost, M. DeLorenzo, and W. W. Thatcher. 2000a. Effect of body condition on reproductive efficiency of lactating dairy cows receiving a timed insemination. Theriogenology 53:1305-1319. 
Moreira, F., C. A. Risco, M. F. A. Pires, J. D. Ambrose, M. Drost, and W. W. Thatcher. 2000b. Use of bovine somatotropin in lactating dairy cows receiving timed artificial insemination. J. Dairy Sci. 83:1237-1247.

Pershing, R. A., M. C. Lucy, W. W. Thatcher, and L. Badinga. 2002. Effects of BST on oviductal and uterine genes encoding components of the IGF system in lactating dairy cows. J. Dairy Sci. 85:3260-3267.

Portaluppi, M. A., and J. S. Stevenson. 2005. Pregnancy rates in lactating dairy cows after presynchronization of estrous cycles and variations of the Ovsynch protocol. J. Dairy Sci. 88:914-921.

Santos, J. E. P., S. O. Juchem, R. L. A. Cerri, K. N. Galvão, R. C. Chebel, W. W. Thatcher, C. S. Dei, and C. R. Bilby. 2004. Effect of $\mathrm{bST}$ and reproductive management on reproductive performance of Holstein dairy cows. J. Dairy Sci. 87:868-881.

Shrestha, H. K., T. Nakao, T. Suzuki, M. Akita, and T. Higaki. 2005. Relationships between body condition score, body weight, and some nutritional parameters in plasma and resumption of ovarian cyclicity during pre-service period in high-producing dairy cows in a subtropical region in Japan. Theriogenology 64:855-866.
Tarazón-Herrera, M. A., J. T. Huber, J. E. P. Santos, H. Mena, L. Nussio, and C. Nussio. 1999. Effects of bovine somatotropin and evaporative cooling plus shade on lactation performance of cows during summer heat stress. J. Dairy Sci. 82:2352-2357.

VanBaale, M. J., D. R. Ledwith, J. M. Thompson, R. Burgos, R. J. Collier, and L. H. Baumgard. 2005. Effect of increased milking frequency in early lactation with or without recombinant bovine somatotropin. J. Dairy Sci. 88:3905-3912.

Vasconcelos, J. L. M., D. G. B. Demétrio, R. M. Santos, J. R. Chiari, C. A. Rodrigues, and O. G. Sá Filho. 2006. Factors potentially affecting fertility of lactating dairy cow recipients. Theriogenology 65:192-200

West, J. W., K. Bondari, and J. C. Johnson. 1990a. Effects of bovine somatotropin on milk yield and composition, body weight, and condition score of Holstein and Jersey cows. J. Dairy Sci. 73:1062-1068.

West, J. W., B. G. Mullinix, J. C. Johnson, Jr., K. A. Ash, and V. N. Taylor. 1990b. Effects of bovine somatotropin on dry matter intake, milk yield, and body temperature in Holstein and Jersey cows during heat stress. J. Dairy Sci. 73:2896-2906. 